\title{
THE SYSTEM OF RICE INTENSIFICATION (SRI) AS A BENEFICIAL HUMAN INTERVENTION INTO ROOT AND SOIL INTERACTION
}

\author{
Anas Iswandi ${ }^{1}{ }^{*}$, Joeli Barison ${ }^{2)}$, Amir Kassam ${ }^{3)}$, Abha Mishra4), O.P. Rupela5), \\ Amod K. Thakur6), T.M. Thiyagarajan7), and Norman Uphoff8)
}

\author{
1) Soil Biotechnology Laboratory, Department of Soil Science and Land Resources, Faculty of Agriculture, Bogor \\ Agricultural University (IPB), Campus IPB Darmaga Bogor 16680 Indonesia; \\ 2) SRI Secretariat, Antananarivo, Madagascar; \\ 3) School of Agriculture, Policy and Development, University of Reading, UK; \\ 4) Agricultural Systems and Engineering Program, Asian Institute of Technology, Thailand; \\ 5) Former Principal Scientist, ICRISAT, Hyderabad, India; \\ 6) Directorate of Water Management, Bhubaneswar, India; \\ 7) Former Director, Centre for Crop and Soil Management Studies, Tamil Nadu Agricultural University, India; \\ 8) Former Director, Cornell International Institute for Food, Agriculture and Development, Ithaca, NY 14853,
} USA

\begin{abstract}
The System of Rice Intensification (SRI) was developed in Madagascar in the ealier 1980 by Fr. Henri de Laulanié. Basic principles of SRI are: (1) the transplanting of young seedlings, preferably only 8-12 days old, this conserves the growth potential that rice plants have if they are transplanted before the start of the fourth phyllochron; (2) The young seedlings are transplanted quickly and quite carefully, taking care to minimize any trauma to the roots, also singly and with wide spacing, in a square pattern usually $25 \mathrm{~cm}$ x $25 \mathrm{~cm}$, or even farther apart if the soil is fertile; (3) Under SRI management, paddy fields are not kept continuously flooded, instead, mostly aerobic soil conditions are maintained throughout the vegetative growth period, either by adding small amounts of water regularly, or by alternate wetting and drying (AWD); (4) a simple mechanical, soil-aerating weeder is used to control weed growth; (5) Although these methods when used with chemical fertilizer will enhance crop yield, the best yields and greatest cost-saving for farmers are attained with application of organic fertilizer or other organic matter, when available. When SRI practices are used together and as recommended, the following results are common: (1) Grain yields are usually increased by $50-100 \%$, or sometimes more, while water applications are reduced by 30 $50 \%$ since there is no continuous flooding, straw yields usually also increase, which is an additional benefit to many farmers; (2) The need to use agrochemicals for crop protection is reduced because SRI plants are naturally more resistant to pest and disease damage; (3) With reduced costs of production, including often reduced labor requirements, farmers' net income is greatly increased with the higher yields; (4) SRI plants are better suited to withstand the effects of climate change, having greater resistance as a rule to most biotic and abiotic stresses; (5) SRI paddy usually gives higher milling out-turn, about $15 \%$, because when milled there is less chaff (fewer unfilled grains) and less breaking of grains. These qualities are probably attributable to the effects of better root systems which can more effectively take up micronutrients from lower soil horizons. Currently, SRI practices has been introduced in many countries with modifications and adaptation to local conditions.
\end{abstract}

Keywords: Conventional rice cultivation, root-soil intervaction, System of Rice Intensification (SRI),

\section{INTRODUCTION}

The System of Rice Intensification (SRI), an alternative approach and set of practices for cultivating irrigated rice that was developed in Madagascar several decades ago, has been making it possible for farmers in many countries to achieve more productive crops of rice from their existing varieties. They can achieve this higher productivity by making certain changes in the way that they manage both the rice plants and the resources that these draw on: mineral soil, soil biota, air, soil moisture, and solar energy. The critical factors in this transformation are enhancing the size and functioning of plant root systems and promoting the abundance and diversity of soil biota. These practices and this approach to cultivation are also being extended now to upland (rainfed) rice production and to other crops, so the effect of SRI concepts and practices is not limited to irrigated rice (http://ciifad.cornell.edu/sri/).
Certainly there are genetic differences between cultivars in how effectively they respond to changes in their growing conditions. However, actual plants (phenotypes, $\boldsymbol{P}$ ) are always the result of interaction between their genetic potential $(\boldsymbol{G})$ and their environment $(\boldsymbol{E})$. This relationship is summarized in the symbolic equation: $\boldsymbol{P}=(f) \boldsymbol{G} \boldsymbol{x} \boldsymbol{E}$. This paper considers how making modifications in rice plants' $\boldsymbol{E}$ can have large and beneficial impacts on $\boldsymbol{P}$.

The most visible effect of SRI management practices is the larger root systems of the resulting plants. Under SRI's mostly aerobic soil conditions, these remain healthy longer and access larger volumes of soil. They continue growing and functioning throughout the crop's growth cycle, rather than suffocate and degenerate as occurs under continuous flooding and hypoxic soil conditions (Kar et al., 1974). Roots' morphology and physiology both reflect and result in changes in the soil biota, which have a large influence on roots' size and 
success. The kind of contrast in root formation that can occur with SRI crop management, compared to what on happens with continuous inundation, can be seen in Figures 1 and 2.

This paper reports on what we have been learning from SRI experience in various countries, both from farmers' fields and from controlled experimental evaluations. It focuses on the growth and performance of rice plant root systems under SRI management with particular interest in the associated soil organisms and their agrobiodiversity that contribute to, and benefit from, the phenotypical differences evoked by SRI practices (Randriamiharisoa and Uphoff, 2006; Uphoff and Kassam, 2009; Uphoff et al., 2009).

Much remains to be evaluated and learned from SRI experience. This paper is a kind of progress report. SRI results to date indicate how important it is to advance our understanding of the many and complex relationships between soil and roots for improvements in overall crop performance. Soil should not be looked upon and analyzed primarily as mineral material; rather we should think in terms of soil systems (Uphoff et al., 2006). These include plant roots and the soil biota along with the biological processes that occur during crop growth as influenced by soil physical, chemical, hydrological and thermal status (Kassam et al., 2009). Soil systems' productive capacity for agricultural purposes depends, quite literally, upon the life in the soil and on the associated regulatory and protective ecosystem processes.

Remarkable differences in root system development can be induced in plants of the same age and same variety by changing their growing environment, particularly below-ground (Figures 1 and 2). Such differences deserve more study than they have received to date, considering not only soil and nutrient relationships, but also the contributions from the soil biota which can affect nutrient availability, production of phytohormones, protection against pathogens, redox potential, and other services (Coleman et al., 2004: Uphoff et al., 2009; Whalen and Sampedro, 2010). This paper seeks to interest others in working with and evaluating these alternative agronomic methods which have such great and important effects on roots. These support better plant growth but also enhanced crop performance, lower crop requirements for irrigation water, and better grain quality.

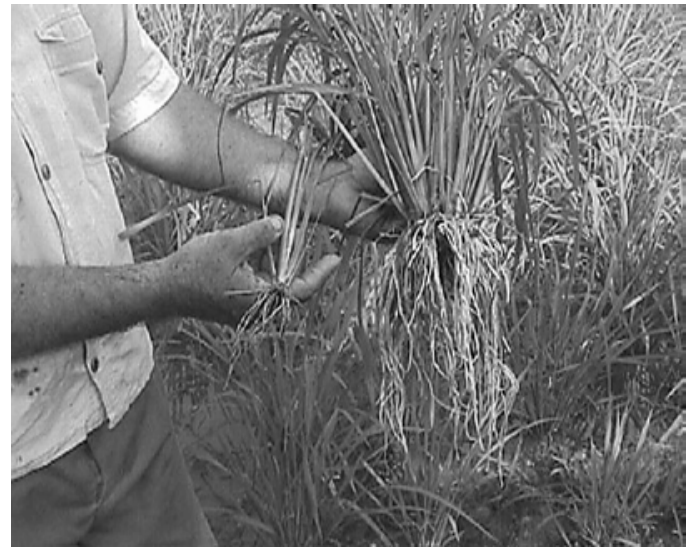

Figure 1. Two rice plants in Cuba both same age (52 DAP) and same genotype (VN2084), being compared by Mr. Luis Romero, San Antonio de los Baños, who started both plants in the same nursery. The plant on left with 5 tillers was being removed from Romero's (flooded) nursery for transplanting when Dr. Rena Perez, who took this picture, was visiting his farm. In Cuba seedlings are usually transplanted at 50-55 days. For comparison, Romero pulled up a rice plant at random from his SRI field, which had been transplanted into an SRI growing environment when 9 days old. Iton had 42 tillers. The next season, the growth and differentiation of SRI rice plants compared to 'normal' plants was videoed weekly by Dr. Perez and posted at: http://ciifad.cornell.edu/sri/countries/cuba/SICAenglish.wmv, with English subtitles. A shorter video with narration in Spanish is also posted on the SRI website at: http://ciifad.cornell.edu/sri/countries/cuba/SICA4web.wmv.

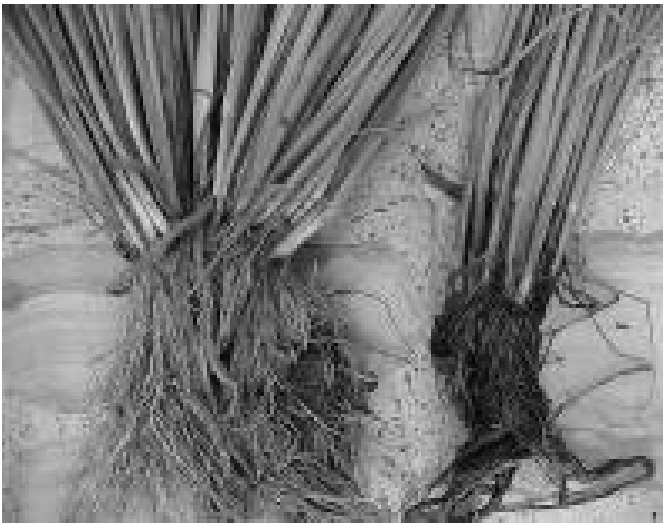

Figure 2. Comparison of rice plants grown in Iran with SRI methods (on left) and with normal flooded methods (on right). Note the differences in color as well as in size. Picture courtesy of Bahman Amiri Larijani, Haraz Technology Development and Extension Centre at Amol, Mazandaran Province, Iran. 


\section{THE SYSTEM OF RICE INTENSIFICATION}

The changes in practice that are recommended, according to the principles of SRI, are just a few and quite simple. Their effect of these changes is to promote more and better root growth as well as to support more active and diverse populations of beneficial soil organisms (Uphoff and Kassam, 2009):

- SRI starts with the transplanting of young seedlings, preferably only 8-12 days old. This conserves the growth potential that rice plants have if they are transplanted before the start of the fourth phyllochron (Nemoto et al., 1995). Under most condition this begins about the $15^{\text {th }}$ day after sowing. Later transplanting of seedlings will contribute to reduced tillering and less root growth ${ }^{1}$.

- The young seedlings are transplanted quickly and quite carefully, taking care to minimize any trauma to the roots, also singly and with wide spacing, in a square pattern usually $25 \times 25 \mathrm{~cm}$, or even farther apart if the soil is fertile. SRI plant populations per $\mathrm{m}^{2}$ are reduced by $80-90 \%$ compared with usual methods which put 3-6 plants in a hill, either in rows or randomly, with close spacing between hills. SRI gives plants more room for root growth and for a corresponding larger canopy.

- Under SRI management, paddy fields are not kept continuously flooded. Instead, mostly aerobic soil conditions are maintained throughout the vegetative growth period, either by adding small amounts of water regularly, or by alternate wetting and drying (AWD). After panicle initiation, a thin layer of water $(1-2 \mathrm{~cm})$ is maintained. ${ }^{2}$ Some farmers who lack access to irrigation have now adapted SRI concepts and practices to rainfed SRI, and just with rainfall are getting better yields than achieved by most farmers who grow their rice conventionally with irrigation. Unsaturated soil conditions, not hypoxic, are more conducive to healthy root growth and more supportive of diverse populations of beneficial (aerobic) soil biota.

- For weed control, which is more necessary when paddy fields are not kept inundated as is the case with flooded paddies, a simple mechanical, soil-aerating weeder is used to control weed growth. While weeds can be managed with herbicides, this does not promote root growth or the agrobiodiversity and abundance of soil organisms that can enhance plant performance.

- Although these methods when used with chemical fertilizer will enhance crop yield, the best yields and greatest cost-saving for farmers are attained with application of compost or other organic matter, as much as possible. This practice improves soil structure, biology and fertility and is definitely conducive to greater root growth and better functioning.
There are a number of variations in the original recommendations of Fr. Henri de Laulanié who assembled these synergistic practices in Madagascar (Laulanié, 1993; Uphoff, 2005). Through two decades of working with Malagasy farmers, he gained many insights into how to provide rice plants with the most favorable growing environment. Still, his suggestions are more like a menu than a recipe. Farmers and researchers are encouraged to understand the principles associated with SRI, to refine them and to advance beyond them, seeking to determine for specific agroecosystems the optimal conditions for rice plant growth.

How these alternative practices increase crop tillering and grain filling, with less senescence of leaves, is easy to see and measure. These effects are easily measureable and clearly documented (Randriamiharisoa and Uphoff, 2002; Ceesay et al., 2006; Thakur et al., 2010). Less easily seen and measured are the much larger, deeper, and longer-lived root systems induced by SRI practices and the associated increases and diversity of soil biota (Randriamiharisoa et al., 2006; Zhao et al., 2010). Data on these below-ground effects are offeredin the sections that follow.

When SRI practices are used together and as recommended, the following results are common, although not always obtained because biological effects are not as consistent or predictable as chemical ones:

- Grain yields are usually increased by $50-100 \%$, or sometimes more, with SRI management, while water applications are reduced by $30-50 \%$ since there is no continuous flooding. Straw yields usually also increase, which is an additional benefit to many farmers. Where rice productivity is at low levels, SRI methods often increase output by multiples rather than increments, as reported from the Aceh region of Indonesia by the NGO Caritas. Introduction of SRI methods there post-tsunami has enabled smallholders to raise their average paddy yields from 2 ton $\mathrm{ha}^{-1}$ to 8.5 ton ha ${ }^{-1}$ (Cook, 2009).

- There is less or no need to use chemical fertilizer if compost can be applied instead. The need to use agrochemicals for crop protection is reduced because SRI plants are naturally more resistant to pest and disease damage. So while SRI is not necessarily an 'organic' cropping system, it can be profitable as an organic system, with little or no transition period and even without premium prices, provided that there is enough biomass and labor available to 'feed the soil' so that the soil can, in turn, 'feed the plants.' SRI practices can make more profitable the expansion of biomass production and the processing and application thereof to enhance soil organic matter.

\footnotetext{
${ }^{1}$ Transplanting is not necessary for SRI crop establishment as farmers in several countries are now adapting SRI principles to direct-seeded rice production. The principle is that if the crop is transplanted, this should be done while the seedlings are still considerably younger than current usual practice with seedlings 3-4 weeks old or more.

${ }^{2}$ Some SRI farmers continue AWD throughout the crop cycle. With no flooding during vegetative growth, plants develop deeper root systems that can take up water from lower soil horizons during the later reproductive phase. What water regime will be preferable depends on factors like soil structure, varietal differences, labor availability.
} 
- With reduced costs of production, including often reduced labor requirements, farmers' net income is greatly increased with the higher yields. While SRI can require more labor initially, during the learning phase (Moser and Barrett, 2003), in many countries SRI practices are reducing farmers' requirements for labor as well as seed, water and production cost (e.g., Sinha and Talati, 2007; Namara et al., 2008). Since practically all varieties, old and new, respond well to SRI management, farmers do not need to purchase new seeds, which is a benefit particularly for farmers with limited economic resources.

- SRI plants are better suited to withstand the effects of climate change, having greater resistance as a rule to most biotic and abiotic stresses. Their ability to withstand the hazards of drought and even of some amount of flooding, as well as to minimize lodging from storm damage (wind and rain) is traceable to SRI plants' larger, deeper root systems as well as to their stronger tillers. Resistance to crop losses from pest and disease damage is also often reported by farmers and documented by researchers in China, India and Vietnam (Uphoff, 2010).

- SRI paddy usually gives higher milling outturn, about $15 \%$, because when milled there is less chaff (fewer unfilled grains) and less breaking of grains. These qualities are probably attributable to the effects of better root systems which can more effectively take up micronutrients from lower soil horizons. They can also continue taking up nitrogen from the soil throughout the crop cycle. If this enhances protein content, this would account for less breakage of grains in milling (Leesawatwong et al., 2005). ${ }^{3}$

The possibility of 'getting more from less' is counterintuitive, to be sure. But there are good, scientifically substantiated reasons for the improved phenotypes. SRI methods, developed inductively based on observation and experimentation, show, for example, that the conventional belief that rice is an aquatic plant (DeDatta, 1981) needs to be reconsidered. While it is true that rice can survive under inundation, it does not necessarily thrive that way.

Similarly, having many fewer plants per $\mathrm{m}^{2}$ can give higher yield, if they are transplanted at a young age and can grow in aerobic soil enriched with organic matter. Dense planting deprives plants' lower leaves of enough solar radiation for photosynthesis. This means that they draw on rather than contribute to the plant's pool of photosynthate. Moreover, because these lower leaves are the main source of energy for the plant's roots (Yoshida, 1981), roots' metabolism is adversely affected by crowding. Research shows that SRI management enhances rice crop nitrogen-use and water-use efficiency, as well as having higher rates of photosynthesis (Zhao 2009; Thakur et al., 2010). All of these benefits are based on the morphology and physiology of rice plant roots.

\section{EVALUATIONS OF SRI EFFECTS ON ROOT SYSTEM DEVELOPMENT AND FUNCTIONING}

The first evaluation of SRI impact on rice roots was in 1998, from the research done by Barison for his baccalaureate thesis for the faculty of agriculture (ESSA) at the University of Antananarivo. Among the measurements made of comparative plant growth parameters was root-pulling resistance (RPR), a measurement validated by IRRI in the 1980s. He found in replicated trials with similar soil conditions (moisture, texture, etc.) that, on average, $28 \mathrm{~kg}$ of force was required to uproot clumps of three plants grown with farmer methods. At the same time, with similar soil conditions, 53 $\mathrm{kg}$ was needed to pull up single SRI-grown plants (Barison, 1998). On a per-plant basis, this was almost a six-fold difference.

Subsequently, as part of his research for a Cornell master's thesis in crop and soil sciences, Barison did more systematic study of the rice roots that resulted from SRI cultivation practices (with organic fertilization and no flooding of the soil) compared with roots produced by the 'improved' system promoted by the government (System de Riziculture Ameliorée, SRA) and by conventional farmer practice. As seen in Table 1 , the resistance to uprooting (RPR) was on average more than 3 times greater for SRI plant roots than for SRA plants, and almost 10 times higher than for conventionally-grown plants.

This can be explained in part by differences in root density ( $\mathrm{cm}$ of roots per $\mathrm{cm}^{-3}$ of soil) at different levels in the soil horizon. In the top $20 \mathrm{~cm}$ of soil, density was seen to be greater for SRA and conventional plants, as shown in Table 2. Then, at $20-30 \mathrm{~cm}$ depth, the three systems of management produced rice plants with root densities practically the same. Below $30 \mathrm{~cm}$, however, the measurements showed significant differences, and at $40-50$ cm depth, SRI root density was 3 times greater than that for SRA rice plants, and almost 4 times greater than for conventional rice plants. Both SRA and conventional cultivation was done under flooded soil conditions.

Table 1. Comparison of root-pulling resistance (RPR) hill-1 in kg, at different stages

\begin{tabular}{lcccc}
\hline Treatments & RPR at panicle initiation & RPR at anthesis & RPR at maturity & Decrease in RPR between anthesis and maturity (\%) \\
\hline SRI with compost & 53.00 & 77.67 & $55.19^{\mathrm{a}}$ & 28.69 \\
SRI without compost & 61.67 & 68.67 & $49.67^{\mathrm{a}}$ & 28.29 \\
SRA with NPK and urea & 44.00 & 55.33 & $34.11^{\mathrm{b}}$ & 38.30 \\
SRA without fertilization & 36.33 & 49.67 & $30.00^{\mathrm{b}}$ & 39.40 \\
Conventional system & 22.00 & 35.00 & $20.67^{\mathrm{b}}$ & 40.95 \\
\hline
\end{tabular}

Number of plants per hill was: SRI = 1, SRA = 2-3, Conventional = 4-6. NPK ratio was 11-22-16

Letters accompanying means indicate whether mean differences were significant (LSD test) at 5\%

Source: Barison (2003)

\footnotetext{
${ }^{3}$ While this study in Thailand documented reduced breakage associated with greater protein in rice grains due to higher nitrogen fertilizer applications, $\mathrm{N}$ uptake and protein content could be enhanced by delayed senescence of roots and leaves. Increased applications of $\mathrm{N}$ fertilizer may, however, reduce the biological value the resulting protein because the profile of amino acids they promote is less balanced and beneficial (Todorov, 1995).
} 
Table 2. Root length density $\left(\mathrm{cm} \mathrm{cm}^{-3}\right.$ ) under SRI, SRA and conventional systems

\begin{tabular}{lccccc}
\hline Treatments & \multicolumn{5}{c}{ Soil layers (cm) } \\
\hline & $0-5$ & $5-10$ & $10-20$ & $20-30$ & $30-40$ \\
SRI with compost & 3.65 & 0.75 & 0.61 & 0.33 & 0.30 \\
SRI without compost & 3.33 & 0.71 & 0.57 & 0.32 & 0.25 \\
SRA with NPK and urea & 3.73 & 0.99 & 0.65 & 0.34 & 0.18 \\
SRA without fertilization & 3.24 & 0.85 & 0.55 & 0.31 & 0.23 \\
Conventional system & 4.11 & 1.28 & 1.19 & 0.36 & 0.09 \\
\hline
\end{tabular}

Source: Barison (2003)

In a subsequent thesis written for the agronomy faculty of the University of Antananarivo, Andry Andriankaja (2001) analyzed the roots as well as aboveground performance of rice plants grown with different methods. His research included assessments of the populations of Azospirillum, $\mathrm{N}$-fixing bacteria living inside rice roots as endophytes. He compared their numbers, according to methods of cultivation, in samples of plant roots taken systematically and counted at the Institut Pasteur in Antananarivo. He found no significant difference in Azospirillum populations in the rhizosphere soil around the roots attributable to different crop management practices. However, a clear association was found between the cultivation methods used (SRI compared with conventional practice), on one hand, and the numbers of tillers per plant and crop yield, on the other (Table 3). Andriankaja's data showed also a strong effect from the kind of soil fertilization used, if any, with organic fertilization increasing all three parameters.

Table 3. Endophytic Azospirillum populations, tillering, and rice yield associated with alternative cultivation practices and nutrient amendments

\begin{tabular}{|c|c|c|c|}
\hline & $\left.\begin{array}{l}\text { Azospirillum } \\
\text { count in roots } \\
\left(10^{3} \text { CFUs mg }\right. \\
1\end{array}\right)$ & $\begin{array}{l}\text { Tillers } \\
\text { plant }^{-1}\end{array}$ & $\begin{array}{c}\text { Yield } \\
\left(\text { ton ha }^{-1}\right)\end{array}$ \\
\hline \multicolumn{4}{|l|}{ CLAY SOIL } \\
\hline $\begin{array}{l}\text { Conventional } \\
\text { cultivation with } \\
\text { no nutrient } \\
\text { amendments }\end{array}$ & 65 & 17 & 1.8 \\
\hline $\begin{array}{l}\text { SRI cultivation with } \\
\text { no nutrient } \\
\text { amendments }\end{array}$ & 1,100 & 45 & 6.1 \\
\hline $\begin{array}{l}\text { SRI cultivation with } \\
\text { NPK amendments }\end{array}$ & 450 & 68 & 9.0 \\
\hline $\begin{array}{l}\text { SRI cultivation with } \\
\text { compost } \\
\text { amendments }\end{array}$ & 1,400 & 78 & 10.5 \\
\hline \multicolumn{4}{|l|}{ LOAM SOIL } \\
\hline $\begin{array}{l}\text { SRI cultivation with } \\
\text { no nutrient } \\
\text { amendments }\end{array}$ & 75 & 32 & 2.1 \\
\hline $\begin{array}{l}\text { SRI cultivation with } \\
\text { compost } \\
\text { amendments }\end{array}$ & 2,000 & 47 & 6.6 \\
\hline
\end{tabular}

Source: Data from Andriankaja (2001), as reported in Randriamiharisoa (2002) with permission

Most significant for understanding roots' functioning was the clear correlation between yield/tiller number and the numbers of endophytic Azospirillum living in the plant roots. This could be due to their fixing nitrogen for the plant and/or their producing plant growth hormones which Azospirillum is known to do (Bottini et al., 1989; Sommers et al., 2005). The mechanisms involved could not be evaluated in this research due to lack of facilities. But it was clear that the populations of these beneficial microorganisms responded positively to SRI management and also to application of organic fertilizer.

That the magnitudes of response differed between clay soil and loam soil was not surprising since the particles in these soils have very different microstructures with different enhancement effects on microbial and fungal populations. The relationships and relative magnitudes shown in Table 3 are more meaningful than the specific numbers reported, since these populations can vary considerably from situation to situation and week to week, affected by soil type, climate, crop variety, and other factors.

With conventional practice, which included flooding of soil, the yield observed, 1.8 ton ha ${ }^{-1}$, was close to the current average yield in Madagascar, around 2 ton $\mathrm{ha}^{-1}$. Using SRI practices with no flooding but also without nutrient amendments, yield more than tripled, to 6.2 ton $\mathrm{ha}^{-1}$. With inorganic nutrient amendments (NPK), SRI practices gave a yield almost 50\% higher, 9.0 ton ha- ${ }^{-1}$. However, when compost was added instead of fertilizer, a practice that benefits the soil biota as well as the plant, yield increased by another $16 \%$, to 10.5 ton $\mathrm{ha}^{-1}$.

Across these four treatments, the corresponding population densities of Azospirillum in the roots went from 65,000 colony-forming units (CFUs) $\mathrm{mg}^{-1}$ with conventional practice, anaerobic soil and no nutrient amendments, to 1.1 million CFUs $\mathrm{mg}^{-1}$ with SRI management, aerobic soil and no amendments. When mineral fertilizer was applied with SRI practices, the microbial population was $60 \%$ less, not surprising since supplying inorganic nutrients can have adverse impacts on soil organisms. With chemical fertilization, the observed increase in yield of $50 \%$ was attributable mostly to the supply of inorganic $\mathrm{N}$ to the plant. With compost amendments, the population of Azospirillum rebounded to 1.4 million $\mathrm{mg}^{-1}$. In this analysis, it was not assumed that the tillering and yield effects were attributable to this single microbial species. Azospirillum was regarded in the study as an indicator of microbial populations overall, being an organism that given laboratory facilities could be counted fairly easily and reliably. This study indicated to Barison and Uphoff that SRI practices can not only induce greater root growth, as seen from Barison's data, but also that SRI roots can function differently in association with the soil biota. These findings prompted further studies by the other co-authors as discussed below. 


\section{MANAGEMENT PRACTICES AND ROOT \\ DEVELOPMENT AFFECT SOIL BIOTIC POPULATIONS}

Evaluations of the effects of SRI practices on rice plant roots, on the associated soil biota, and on soil biochemical activity were begun at Tamil Nadu Agricultural University in 2001, under the direction of Thiyagarajan, who was at the time director of TNAU's Centre for Crop and Soil Management Studies. Thesis research by Nisha (2002) confirmed greater root length and root volume, as well as differences in cation exchange capacity (CEC), ATPase activity, and cytokinin content of roots when plants were grown with SRI methods (Table 4). CEC reflects the capacity of roots to absorb cations and thus vital nutrients; ATPase is a key enzyme required for the absorption of nutrients; and cytokinin is a growth hormone involved in cytogenesis, being synthesized in the root tips and translocated to other parts of the plant. SRI root systems are thus not only larger, but function more effectively for the support of rice plants.

Further assessments of the effects of SRI management practices documented how changing practices could alter the microbial profile as well as the abundance of beneficial soil microorganisms. The SRI practices assessed included younger seedlings, soilaerating weeding with a mechanical weeder, water management to avoid continuous soil saturation, and green manures to enhance soil organic matter. These had positive effects on the soil biota as seen in Table 5 .

The numbers of all aerobic bacteria in the SRI rhizosphere were increased by more than $50 \%$ before and during panicle initiation, compared to those in the rhizosphere of conventionally-grown rice of same variety. The populations of Azospirillum also increased similarly, while Azotobacter, another diazotroph $\left(\mathrm{N}_{2}\right.$-fixing bacterium) and phosphate-solubilizing bacteria increased by even more, about 75\%. During panicle initiation, the numbers of diazotrophs were more than twice as high under SRI management as conventional practice. Throughout the crop cycle, not only were more bacteria found in SRI rhizospheres ovrall, but there were even more of those species that enhance plants' nutrient availability. This could be explainable by greater supply of root exudates secreted into the soil by SRI roots, which are supplied with more sugars and other compounds produced photosynthetically in the canopy, as discussed below.

Table 4. Root characteristics and activity in the crop under different crop management conditions, Coimbatore, India, wet season, 2001-2002

\begin{tabular}{|c|c|c|c|c|c|}
\hline \multirow[b]{2}{*}{ Parameter } & \multirow[b]{2}{*}{ Treatment } & \multicolumn{4}{|c|}{ Crop growth stages } \\
\hline & & Transplanting & Active tillering & Panicle initiation & Flowering \\
\hline \multirow{2}{*}{ Total root length (m) } & Conventional & 1.02 & 6.08 & 17.42 & 55.71 \\
\hline & SRI & 0.88 & 22.5 & 31.05 & 67.50 \\
\hline \multirow{2}{*}{ Root volume (cc hill-1) } & Conventional & 1.48 & 10.7 & 25.5 & 42.5 \\
\hline & SRI & 0.83 & 15.5 & 26.3 & 57.5 \\
\hline \multirow{2}{*}{ CEC of dried and milled roots (me $100 \mathrm{~g}^{-1}$ of dry root) } & Conventional & NA & 7.2 & 9.8 & 10.6 \\
\hline & SRI & NA & 10.6 & 14.6 & 13.4 \\
\hline \multirow{2}{*}{ ATPase activity of fresh root ( $\mu \mathrm{g}$ of inorganic $\mathrm{P} \mathrm{g}^{-1} \mathrm{hr}^{-1}$ ) } & Conventional & NA & 0.24 & 0.53 & 0.62 \\
\hline & SRI & NA & 0.34 & 0.69 & 0.74 \\
\hline \multirow{2}{*}{ Cytokinin content of roots $\left(\mathrm{pmol} \mathrm{g}^{-1}\right)$} & Conventional & NA & 46.2 & 73.6 & 50.5 \\
\hline & SRI & NA & 58.9 & 86.0 & 72.5 \\
\hline
\end{tabular}

Conventional practice: 24-day-old seedlings; irrigating to $5 \mathrm{~cm}$ depth one day after disappearance of ponded water; hand weeding twice; recommended fertilizers; SRI practice: 14-day-old seedlings; $2 \mathrm{~cm}$ irrigation, after hairline cracks in the soil surface appeared, up to panicle initiation; after PI, irrigate one day after disappearance of ponded water; inter-cultivation with rotary weeder 4 times at 10-day intervals; recommended fertilizer plus green leaf manure. Source: Nisha (2002).

Table 5. Microbial populations in the rhizosphere soil crop under different crop management conditions, Coimbatore, India, wet season, 2001-2002

\begin{tabular}{|c|c|c|c|c|c|}
\hline \multirow[b]{2}{*}{ Parameter } & \multirow[b]{2}{*}{ Treatment } & \multicolumn{4}{|c|}{ Crop growth stages $^{1}$} \\
\hline & & Active tillering & Panicle initiation & Flowering & Maturity \\
\hline \multirow{2}{*}{ Total bacteria } & Conventional & 9.35 & 14.91 & 9.73 & 7.64 \\
\hline & SRI & 14.66 & 21.64 & 10.99 & 7.51 \\
\hline \multirow{2}{*}{ Azospirillum } & Conventional & 4.69 & 7.39 & 3.13 & 1.42 \\
\hline & SRI & 7.17 & 9.08 & 4.23 & 1.52 \\
\hline \multirow{2}{*}{ Azotobacter } & Conventional & 8.88 & 25.57 & 10.45 & 5.56 \\
\hline & SRI & 20.15 & 31.17 & 10.92 & 6.45 \\
\hline \multirow{2}{*}{ Total diazotrophs } & Conventional & 9.11 & 10.52 & 7.14 & 4.71 \\
\hline & SRI & 14.62 & 22.91 & 7.68 & 5.43 \\
\hline \multirow{2}{*}{ Phosphobacteria } & Conventional & 9.15 & 17.65 & 7.76 & 2.28 \\
\hline & SRI & 16.19 & 23.75 & 13.79 & 2.66 \\
\hline
\end{tabular}

${ }^{1}$ Numbers are square-root transformed values of populations per gram of dry soil

Conventional practice: 24-day-old seedlings; irrigating to $5 \mathrm{~cm}$ depth one day after disappearance of ponded water; hand weeding twice; recommended fertilizers; SRI practice: 14-day-old seedlings; $2 \mathrm{~cm}$ irrigation, after hairline cracks in the soil surface appeared, up to panicle initiation; after PI, irrigate one day after disappearance of ponded water; inter-cultivation with rotary weeder 4 times at 10-day intervals; recommended fertilizer plus green leaf manure. Source: Gayathry (2002), from Uphoff et al. (2009). 
Table 6. Microbial activities in the rhizosphere soil under different crop management conditions, Coimbatore, India, dry season, 2002

\begin{tabular}{|c|c|c|c|c|c|c|}
\hline \multirow{2}{*}{ Parameter } & \multirow{2}{*}{ Treatment } & \multicolumn{5}{|c|}{ Crop growth stage $^{1}$} \\
\hline & & Active tillering & Panicle initiation & Flowering & Grain filling & Maturity \\
\hline Dehydrogenase activity & Conventional & 81 & 263 & 78 & 24 & 16 \\
\hline$\left(\mu \mathrm{g}\right.$ TPF g ${ }^{-1}$ soil $\left.24 \mathrm{hr}^{-1}\right)$ & SRI & 369 & 467 & 139 & 95 & 42 \\
\hline Urease activity & Conventional & 189 & 1,794 & 457 & 134 & 87 \\
\hline$\left(\mu \mathrm{g} \mathrm{NH}_{4}-\mathrm{N} \mathrm{g}^{-1}\right.$ soil $\left.24 \mathrm{hr}^{-1}\right)$ & SRI & 230 & 2,840 & 618 & 228 & 173 \\
\hline Acid phosphate activity & Conventional & 1,800 & 2,123 & 957 & 384 & 214 \\
\hline ( $\mu \mathrm{g}$ p-Nitrophenol g ${ }^{-1}$ soil $\mathrm{hr}^{-1}$ ) & SRI & 1,984 & 2,762 & 2,653 & 995 & 686 \\
\hline Alkaline phosphate activity & Conventional & 261 & 372 & 332 & 124 & 120 \\
\hline ( $\mu \mathrm{g}$ p-Nitrophenol g ${ }^{-1}$ soil $\mathrm{hr}^{-1}$ ) & SRI & 234 & 397 & 324 & 189 & 146 \\
\hline Nitrogenase activity & Conventional & - & 3.15 & 7.63 & - & 1.94 \\
\hline (nano moles $\mathrm{C}_{2} \mathrm{H}_{4} \mathrm{~g}^{-1}$ soil $24 \mathrm{hr}^{-1}$ ) & SRI & - & 3.70 & 11.13 & - & 1.87 \\
\hline
\end{tabular}

Values are square-root transformed values per gram of dry soil Conventional and SRI practices were the same as reported in Table 4 Source: Gayathry (2002) from Uphoff et al. (2009)

Differences in microbial populations should be reflected in different in the levels of microbial activity in the rhizosphere soil. Gayathry (2002) measured the levels of enzymes that reflect processes of $\mathrm{N}$ and $\mathrm{P}$ mobilization and uptake in the soil. These were significantly greater at almost all phases of crop growth when SRI practice altered the management of plants, soil, water and nutrients, as seen in Table 6 . While the reasons for these differentials were not clear, they have been documented in other studies as well.

Starting in 2004, the World Wide Fund for Nature (WWF) began supporting SRI evaluation and then its dissemination in Andhra Pradesh state of India, working with the state agricultural university (ANGRAU), the Directorate of Rice Research of the Indian Council for Agricultural Research, and the International Crop Research Institute for the Semi-Arid Tropics (ICRISAT), through its Dialogue Project on Food, Water and the Environment with ICRISAT.

Some 200 farmers across 10 districts of the state participated, using SRI practices and conventional practices on the same farms, so that any effects attributable to farmer and soil differences were minimized. ICRISAT undertook soil biology and root studies with 27 farmers who were willing to cooperate over four seasons. Their average yields over this period were 7.68 ton $\mathrm{ha}^{-1}$ with SRI cultivation methods compared with 6.15 ton $^{-1} a^{-1}$ with farmers' usual practices (Rupela et al., 2006).

Significant differences in the growth of root systems under SRI management were confirmed in this study (Table 7). Indeed, the differences were quite dramatic. Rice plants in the SRI plots had about 10 times more root mass, about 5 times more root length density, and about 7 times more root volume in the top $30 \mathrm{~cm}$ of soil profile, compared with roots in the plots of flooded rice. Root length in the top $15 \mathrm{~cm}$ of soil on SRI plots was $19.8 \mathrm{~km} \mathrm{~m}^{3}$ vs. $2.4 \mathrm{~km} \mathrm{~m}^{3}$ with usual practice (Rupela et al., 2006).

However, differences in total microbial numbers and activity were not as great (Table 8). The composition of the soil biota apparently has more bearing on crop performance than do aggregated measures. Total numbers of bacteria and fungi in the soils of SRI and control plots were not much different. However, mean microbial biomass carbon (MBC) was 2-41\% higher in three of the four seasons, even if differences were not statistically significant because of their wide variability. The numbers of certain microbial species -- phosphate solubilizers, and siderophore producers, which help plants acquire Fe -were higher in SRI plots, but again the differences were not statistically significant.

Table 7. Root dry weight, root length density, and root volume of rice in top $30 \mathrm{~cm}$ soil profile aton harvesting stage from ten farmer's fields, Andhra Pradesh, India, rainy season, 2006

\begin{tabular}{|c|c|c|c|c|c|c|c|c|c|}
\hline & \multicolumn{3}{|c|}{$\begin{array}{l}\text { Root oven dry weight } \\
\left(\mathrm{g} \mathrm{m}^{-3}\right)\end{array}$} & \multicolumn{3}{|c|}{$\begin{array}{l}\text { Root length density } \\
\left(\mathrm{m} \mathrm{m}^{-3}\right)\end{array}$} & \multicolumn{3}{|c|}{$\begin{array}{l}\text { Root volume } \\
\left(\mathrm{cm}^{3} \mathrm{~m}^{-3} \text { soil }\right)\end{array}$} \\
\hline Depth & SRI & Conv. & Mean & SRI & Conv. & Mean & SRI & Conv. & Mean \\
\hline $0-15 \mathrm{~cm}$ & 392 & 19 & 206 & 19,820 & 2,386 & 11,103 & 3,391 & 252 & 1,822 \\
\hline $15-30 \mathrm{~cm}$ & 193 & 19 & 106 & 10,572 & 2,243 & 6,408 & 1,740 & 242 & 991 \\
\hline $\mathrm{SE} \pm$ & \multicolumn{2}{|c|}{$34.7 *(38.9)$} & $27.5^{* * *}$ & \multicolumn{2}{|c|}{$1,816.2 *(2,122.7)$} & $1,501.0^{* * *}$ & \multicolumn{2}{|c|}{$292.5 *(331.6)$} & $234.5^{* * *}$ \\
\hline Mean & 293 & 19 & & 15,196 & 2,315 & & 2,566 & 247 & \\
\hline $\mathrm{SE} \pm$ & \multicolumn{3}{|c|}{$21.2^{* *}$} & \multicolumn{2}{|c|}{$1,022.6^{* *}$} & & \multicolumn{2}{|c|}{$174.8^{* *}$} & \\
\hline CV (\%) & \multicolumn{2}{|c|}{79} & & \multicolumn{2}{|c|}{77} & & \multicolumn{2}{|c|}{79} & \\
\hline
\end{tabular}

$*, * *$, and $* * *$ statistically significant at $0.05,0.01$ and 0.001 level of significance, respectively

Values in parentheses are SEs to compare means within the same treatment

Source: Rupela et al. (2006) 
Table 8. Properties of soil samples from SRI and control rice plots at fields of selected farmers in Andhra Pradesh, India, during four seasons (post-rainy 2004/2005 to rainy 2006)

\begin{tabular}{|c|c|c|c|c|}
\hline Parameter & SRI & Control* & $\mathrm{SE}+$ & $\mathrm{CV}(\%)$ \\
\hline Bacteria ( $\log _{10} \mathrm{~g}^{-1}$ dry soil) & 6.15 & 6.18 & $0.04 \overline{4}^{\mathrm{NS}}$ & 1.4 \\
\hline Fungi ( $\log _{10} \mathrm{~g}^{-1}$ dry soil $)$ & 4.35 & 4.35 & $0.029^{\mathrm{NS}}$ & 1.3 \\
\hline Siderophore producers ( $\log _{10} \mathrm{~g}^{-1}$ dry soil) & 4.48 & 4.33 & $0.117^{\mathrm{NS}}$ & 5.3 \\
\hline Phosphate solubilizers ( $\log _{10} \mathrm{~g}^{-1}$ dry soil) & 3.40 & 3.28 & $0.154^{\mathrm{NS}}$ & 9.2 \\
\hline Pseudomonas fluorescens ( $\log _{10} \mathrm{~g}^{-1}$ dry soil) & 4.20 & 4.20 & $0.035^{\mathrm{NS}}$ & 1.7 \\
\hline $\mathrm{N}_{2}$-fixers ( $\log _{10} \mathrm{~g}^{-1}$ dry soil) & 4.47 & 4.20 & $0.020^{* *}$ & 0.9 \\
\hline Microbial biomass carbon (mg kg ${ }^{-1}$ soil) & 1242 & 1187 & $58.1^{\text {NS }}$ & 9.6 \\
\hline Microbial biomass nitrogen ( $\mathrm{mg} \mathrm{kg}^{-1}$ soil) & 30 & 25 & $0.7^{* *}$ & 4.9 \\
\hline Dehydrogenase ( $\mu \mathrm{g}$ TPF $\left.g^{-1} 24 \mathrm{~h}^{-1}\right)$ & 114 & 93 & $3.0 * *$ & 5.7 \\
\hline Total N (mg kg-1 soil) & 1082 & 1050 & $15.0^{\mathrm{NS}}$ & 2.8 \\
\hline Total P (mg kg ${ }^{-1}$ soil) & 589 & 545 & $5.7^{\mathrm{NS}}$ & 2.0 \\
\hline Available P (mg kg-1 soil) & 20.2 & 17.8 & $0.60^{\mathrm{NS}}$ & 6.3 \\
\hline Organic carbon (\%) & 1.06 & 1.06 & $0.002^{\mathrm{NS}}$ & 0.3 \\
\hline
\end{tabular}

* Mean from plots where farmers used their usual practices

** = Significant at 0.01 level of significance, NS = Not significant. Source: Rupela et al. (2006)

Three differences between the two sets of plots were significant at the 0.01 confidence level: numbers of nitrogen $\left(\mathrm{N}_{2}\right)$ fixing bacteria, microbial biomass nitrogen (MBN), and levels of dehydrogenase (Table 8). This latter enzyme, which oxidizes a substrate by transferring one or more hydrogen ions $\left[\mathrm{H}^{-}\right]$to an acceptor, usually $\mathrm{NAD}^{+} / \mathrm{NADP}^{+}$or a flavin coenzyme such as $\mathrm{FAD}$ or FMN, is considered to be an indicator of the general level of life in the soil. Total $\mathrm{N}$ and total $\mathrm{P}$ as well as available $\mathrm{P}$ were also higher in SRI plots, but the differences were not statistically significant.

A confounding factor in this study was measurements taken in both rainy and post-rainy seasons were combined. The latter soil conditions are more aerobic and thus quite different from the former, because many farmers were not able, or did not try, to control and limit their water applications in the rainy season as recommended. Thus, their soils were more anaerobic than is the norm for SRI use.

Grain yields from SRI plots were higher in all four seasons, and this difference was statistically significant. SRI yields ranged from 6.9-8.2 ton ha ${ }^{-1}$ compared to 5.4-6.75 ton ha ${ }^{-1}$ under conventional management. These increases of $22-28 \%$ were less than those reported from a number of other SRI evaluations, such as in eastern Indonesia, where a $78 \%$ average increase in yield was documented from on-farm comparison trials $(\mathrm{N}=12,133)$ conducted over nine seasons, 2002-2006 (Sato and Uphoff, 2007).

More recently, researchers at the Agricultural University of Bogor (IPB) in Indonesia have been doing soil biology studies to evaluate SRI crop management with regard to greenhouse gas emissions from SRI vs. conventional plots. Confirming the results reported above, they found significant differences in the numbers of beneficial bacteria in the rhizospheres of plants when SRI practices are used, especially with organic fertilization. Roots and soil biota in replicated SRI treatments were compared with those from conventional rice production using NPK fertilizer: SRI practices also using NPK fertilizer; SRI practices with organic fertilization (compost); and SRI practices applying NPK plus a bioorganic fertilizer. ${ }^{4}$
The comparisons shown in Table 9 indicate that total population of bacteria in treatment plots doubled with the combined effect of inorganic and organic fertilization using SRI methods, while organic fertilization with SRI methods produced a total population two-thirds higher than with application of inorganic fertilizer. Specifically, organic fertilization with SRI practices contributed to almost four times more Azospirillum, and almost doubled numbers of Azotobacter and phosphobacteria.

Table 9. Total microbes and numbers of beneficial soil microbes $\left.(\mathrm{CFU} \mathrm{g})^{-1}\right)$ in plant rhizosphere under conventional and SRI rice cultivation methods at Tanjung Sari, Bogor district, Indonesia, February-August 2009

\begin{tabular}{lcccc}
\hline Treatments & $\begin{array}{c}\text { Total } \\
\text { microbes } \\
\left(\times 10^{5}\right)\end{array}$ & $\begin{array}{c}\text { Azotobacter } \\
\left(\times 10^{3}\right)\end{array}$ & $\begin{array}{c}\text { Azospirillum } \\
\left(\mathrm{x} 10^{3}\right)\end{array}$ & $\begin{array}{c}\text { PSM } \\
\left(\mathrm{x} 10^{4}\right)\end{array}$ \\
\hline Conventional (T0) & $2.3 \mathrm{a}$ & $1.9 \mathrm{a}$ & $0.9 \mathrm{a}$ & $3.3 \mathrm{a}$ \\
Inorganic SRI (T1) & $2.7 \mathrm{a}$ & $2.2 \mathrm{a}$ & $1.7 \mathrm{ab}$ & $4.0 \mathrm{a}$ \\
Organic SRI (T2) & $3.8 \mathrm{~b}$ & $3.7 \mathrm{~b}$ & $2.8 \mathrm{bc}$ & $5.9 \mathrm{~b}$ \\
$\begin{array}{l}\text { Inorganic SRI + BF } \\
\text { (T3) }\end{array}$ & $4.8 \mathrm{c}$ & $4.4 \mathrm{~b}$ & $3.3 \mathrm{c}$ & $6.4 \mathrm{~b}$ \\
\hline
\end{tabular}

CFU = colony forming units; PSM = Phosphate-solubilizing microbes; $\mathrm{BF}=$ Bio-organic fertilizer (see fn 4)

Values with the different letters in a column are significantly different by LSD at the 0.05 level

Treatments: $T 0=20 \times 20 \mathrm{~cm}$ spacing, 30 day seedlings, 6 seedlings/hill, $5 \mathrm{~cm}$ flooding depth of water, fertilized with inorganic NPK (250 kg urea, $200 \mathrm{~kg} \mathrm{SP}-18,100 \mathrm{~kg} \mathrm{KCl} \mathrm{ha}^{-1}$ ); T1, T2, T3 = All 30 x $30 \mathrm{~cm}$ spacing, 610 day seedlings, 1 seedling/hill, moist soil or intermittent irrigation, with different fertilization: $T 1=$ same inorganic NPK as $T 0 ; T 2=5$ ton $^{-1}{ }^{-1}$ of organic fertilizer (compost); T3 = same inorganic NPK as in $T 0+300 \mathrm{~kg}$ $\mathrm{ha}^{-1}$ bioorganic fertilizer

Source: Anas et al. (2009)

Such numbers will vary from one set of trials to another because of soil, climate and other factors, so many more such evaluations should be done to gain a better understanding of the factors that affect bacterial population dynamics in conjunction with crop, soil, water and nutrient management variables. However, it does appear SRI practices, respectively and taken together, contribute to positive SRI crop results by creating conditions in which beneficial soil microbes prosper.

\footnotetext{
${ }^{4}$ The bio-organic fertilizer (BF) used was FERTISMART, which is commercially available and advertised as containing rock phosphate and dolomite (calcium magnesium carbonate), plus large numbers of beneficial bacteria (Azotobacter, Azospirillum and Aspergillus niger).
} 
And to the extent that these organisms thrive, so do plants through plant root-microbial interactions and collaboration.

IPB researchers examined the different microbial populations in the root zone at three successive stages of rice crop growth: at active tillering stage, at panicle initiation (PI), and at flowering. Figure 3 shows the measured differences for respective groupings of microbes in the root zones of plants grown with SRI methods (white) and conventionally-grown plants (solid), in these three stages of the crop cycle.

To assess the impact of different soil management practices on soil microbial activity, IPB researchers, like those at Tamil Nadu Agricultural University (Table 5), evaluated levels of enzymes in soil samples from the root zones of the respective plots. Dehydrogenase levels were consistently higher, particularly during active tillering, in SRI plant root zones, and substantially higher throughout the vegetative and reproductive stages. Other biochemical products of microbial activity that facilitate mineralization of $\mathrm{N}$ and $\mathrm{P}$ were also seen to be higher during different stages of crop development, contributing to enhanced plant nutrition and ultimate crop yield.

Why certain beneficial soil organisms should be more numerous and more active in and around the roots of rice plants grown with SRI management practices remains to be studied more to reach tenable conclusions. Having mostly aerobic soil conditions-in contrast to the anaerobic conditions of rice grown in conventionally flooded paddies-explains a great deal of the difference, especially with enhancement of organic matter in the soil, plus any active soil aeration from following the recommended SRI weeding practices. Use of a rotating hoe or conoweeder implement puts more organic matter (weeds) into the soil for decomposition and nutrient recycling.

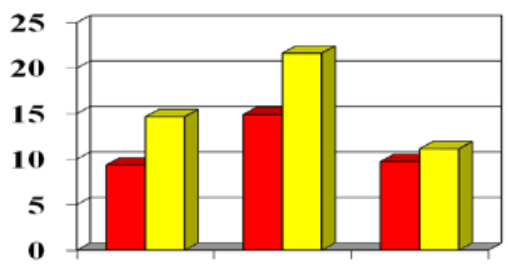

Total bacteria

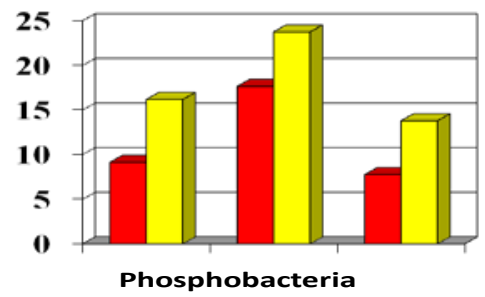

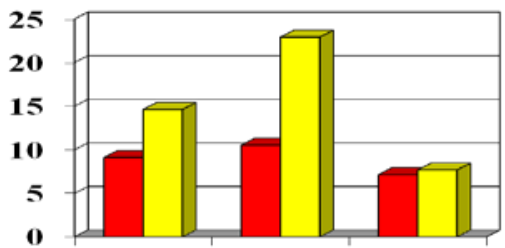

Total diazotrophs

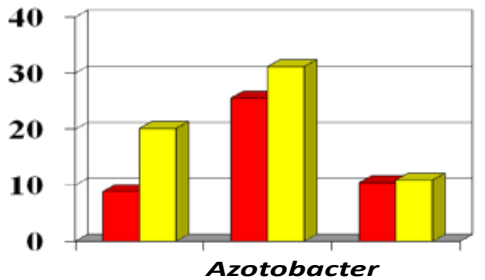

solid bars = conventional management; white bars = SRI management

Figure 3. Microbial populations in the rhizosphere soil with rice plants grown crop under different management regimes at active tillering,

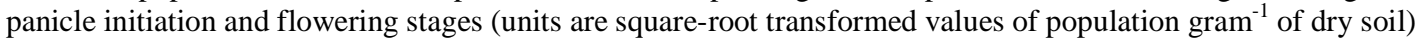

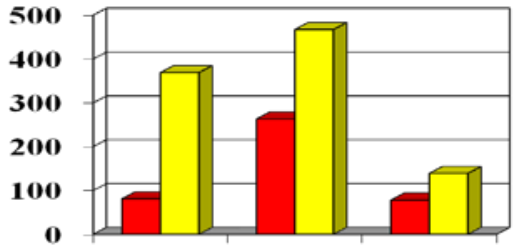

Dehydrogenase activity ( $\mu$ g TPF)

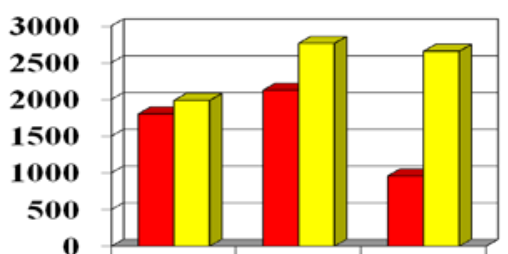

Acid phosphate activity ( $\mu \mathrm{g}$ p-Nitrophenol)
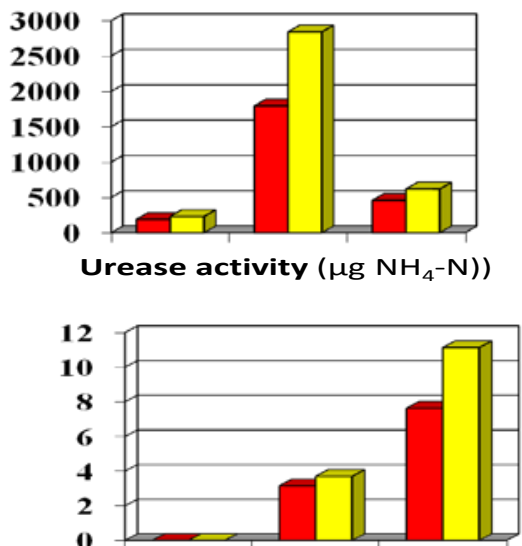

Nitrogenase activity (nano $\mathrm{mol} \mathrm{C}_{2} \mathrm{H}_{4}$ )

solid bars = conventional management; white bars = SRI management

Figure 4. Indicators of microbial activity in rhizosphere soil with rice plants grown under different management regimes at active tillering, panicle initiation and flowering stages (units are square-root transformed values of population gram ${ }^{-1}$ of dry soil) 


\section{ROOT SYSTEM DEVELOPMENT IS AFFECTED BY NURSERY MANAGEMENT PRACTICES}

The improved growth of SRI rice plant root systems begins early, according to experiments conducted at the Asian Institute of Technology evaluating the effects of nursery seedbed management and of transplanting seedlings, at different ages, into a field that was unflooded or flooded (Mishra and Salokhe, 2008). The research compared the root and shoot characteristics of younger (12-day) vs. older (30-day) seedlings grown in a wet seedbed (WSB - flooded) or a dry seedbed (DSB - upland), and then assessed how such seedlings fared in producing tillers and dry matter under flooded (F) vs. nonflooded (NF) field soil conditions.

From the different nursery seedbeds, it was seen that at germination and in the initial growth phase, the dry seedbed (DSB) was better than the wet seed (WSB). The former helped shorten phyllochron length and produced seedlings with a better roots and shoot characteristics. After transplanting, it was found that root length density (RLD) was favorably affected by the age of seedlings (12d $>$ 30d), by seedbed management (DSB > WSB), and by water regimes in the main field at early growth stage (NF $>$ F).

For older seedlings, it was seen that flooded soil was more conducive to greater root length density, but at shallow soil depths and not for deep root growth (Table 10). Conversely, younger seedlings raised in a dry seedbed had the best growth, and had deeper root growth, when transplanted into a field with only intermittent irrigation and mostly aerobic soil conditions. This differentiation could be due to a preference for shoot growth over root growth in older seedlings and a dominance of $\mathrm{NH}_{4}{ }^{+}$in the soil solution which under a reduced environment causes roots to remain mostly in the upper soil layer (Sah and Mikkelsen, 1983).

Non-flooded soil, in contrast, generally improved root growth in the subsoil layer, but this effect was seen more in seedlings transplanted at a younger age (12 d) than older ones (30d). The better uptake of $\mathrm{N}$ by younger seedlings grown in a dry seedbed was also seen as a reason for greater root length density and for a greater number of lateral roots that improved the plants' acquisition of nutrients from the soil.

In these trials, higher tiller and root production was achieved from using younger seedlings (12 d) raised in a dry seedbed, whether transplanted into flooded or nonflooded soil, due to better root growth (Figure 5). This adaptive trait could be exploited to manage rice crops under limited water applications without compromising grain yield. However, because these factors are highly interactive, this relationship should be assessed further with different soil and varietal characteristics.

These trials indicated that under all nursery and field conditions, both wet and dry, younger seedlings led to more root length density, especially when raised in an unflooded nursery and transplanted into an unflooded field. Younger seedlings raised in an unflooded nursery also had considerably higher nitrogen in their shoots. On the other hand, older seedlings kept in the nursery longer and transplanted at 30 days, whether from aerobic or anaerobic soil, had better root growth under flooded field conditions.

This finding could explain why the flooding of paddies is so widespread. Few farmers have had the confidence to transplant very young seedlings. When using older seedlings, they observed better root growth and crop performance under flooded conditions, so flooding became the norm. If they would try younger seedlings, however, they would find that they get better plant growth and yield from having both their nurseries and their fields unflooded, with soil kept just moist enough to meet the needs of the rice plants and their associated soil organisms, and not so much water as to make the soil hypoxic.

Rice is a remarkable cereal plant for having the ability to survive under flooded conditions, by forming aerenchyma in its roots. These air pockets permit oxygen to diffuse passively to root tissues and cells, even though under flooding, as noted above, by time of flowering, a majority of the root system will have degenerated due to hypoxia. SRI experience and agronomic investigations are showing that rice, contrary to popular opinion, is not an aquatic plant. As seen from the research of Puard et al. (1989), aerenchyma formation is an adaptation, not an ideal.

Table 10. Effects of seedbed management, seedling age, and water regimes on root length density (RLD) and N shoot content at 45 days after transplanting

\begin{tabular}{|c|c|c|c|c|c|c|c|c|c|}
\hline \multirow{2}{*}{$\begin{array}{c}\text { Seedbed } \\
\text { management }\end{array}$} & \multirow{2}{*}{$\begin{array}{c}\text { Field } \\
\text { water regime }\end{array}$} & \multicolumn{2}{|c|}{$\begin{array}{c}\text { RLD }\left(\mathrm{cm} \mathrm{cm}^{-3}\right) \\
\text { in upper soil layer }\end{array}$} & \multicolumn{2}{|c|}{$\begin{array}{l}\text { RLD }\left(\mathrm{cm} \mathrm{cm}^{-3}\right) \\
\text { In sub-soil layer }\end{array}$} & \multicolumn{2}{|c|}{$\begin{array}{l}\text { Total RLD } \\
\left(\mathrm{cm} \mathrm{cm}^{-3}\right)\end{array}$} & \multicolumn{2}{|c|}{$\begin{array}{l}\text { N content in plant shoot } \\
\left(\mathrm{mg}^{\text {-pot}}\right)\end{array}$} \\
\hline & & 12 days* & 30 days* & 12 days & 30 days & 12 days & 30 days & 12 days & 30 days \\
\hline Dry & Flooded & $5.78 \pm 0.14$ & $4.55 \pm 0.08$ & $1.97 \pm 0.13$ & $1.30 \pm 0.04$ & 7.75 & 5.84 & $321.75 \pm 4.83$ & $253.88 \pm 4.82$ \\
\hline Dry & Nonflooded & $5.35 \pm 0.18$ & $4.25 \pm 0.16$ & $2.55 \pm 0.14$ & $1.20 \pm 0.08$ & 7.90 & 5.46 & $312.75 \pm 7.68$ & $181.88 \pm 2.45$ \\
\hline Wet & Flooded & $5.21 \pm 0.13$ & $4.26 \pm 0.17$ & $1.77 \pm 0.12$ & $1.66 \pm 0.11$ & 6.98 & 5.92 & $274.50 \pm 9.04$ & $205.50 \pm 2.53$ \\
\hline Wet & Nonflooded & $5.14 \pm 0.12$ & $3.22 \pm 0.20$ & $1.92 \pm 0.12$ & $1.92 \pm 0.12$ & 7.06 & 5.01 & $243.75 \pm 5.00$ & $184.63 \pm 3.09$ \\
\hline
\end{tabular}

*Age of seedlings at transplanting. Table adapted from Mishra and Salokhe (2008) 


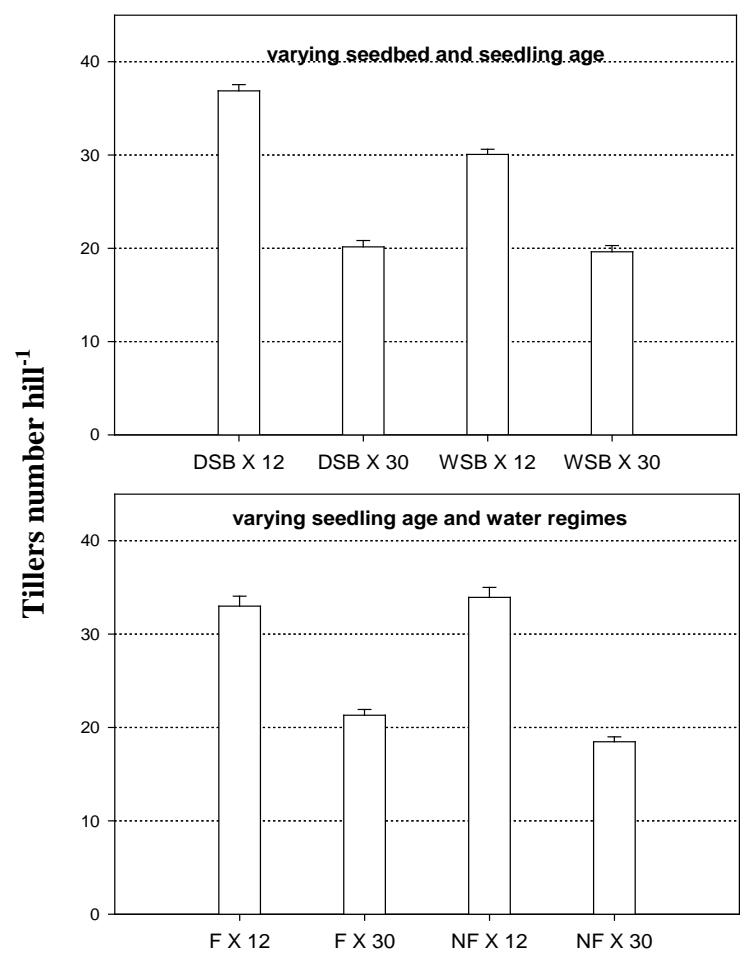

Figure 5. Tiller development in rice plants at 45 days after transplanting considering interaction effects of seedbed (DSB vs. WSB), seedling age (12 days old vs. 30 days old), and field water regimes

$(\mathrm{F}=$ flooded vs. $\mathrm{NF}=$ nonflooded $) .(\mathrm{N}=16)$. Error bars show S.E.

\section{IMPACTS ON ROOT GROWTH AND XYLEM EXUDATION RATES}

Beyond the initial growth phase of rice plants, roots' functioning is further affected by alternative management systems as plants proceed into and through their grain production stages. Research has been done at the Water Technology Centre in Bhubaneswar, India, measuring among other parameters, root growth and xylem exudation rates at the crop's early ripening stage, when active grain-filling is starting. This research showed that with SRI management, roots per hill are nearly twice as heavy and grow deeper, with more than double the length and double the volume compared to rice plants grown with the practices recommended proposed by India’s Central Rice Research Institute (Table 11).

Total root length in SRI (single-plant) hills was found to be twice as great as in hills grown with RMP. This indicates a substantial improvement in the capacity of SRI plants to absorb more water and nutrients from the soil. Given the lower plant density under SRI management, root dry weight and root volume were not significantly different on a per-unit area basis between SRI and conventionally-grown rice. On the other hand, the amount of xylem exudates transported toward the shoot, even when measured on a per-unit area basis, were significantly greater under SRI. This indicates that SRI roots were more active than RMP roots at the earlyripening stage (Table 11 ).

Table 11. Comparison of root growth parameters and xylem exudates transported from plant roots toward shoots in SRI and recommended management practices (RMP) crops at early-ripening stage

\begin{tabular}{|c|c|c|c|c|}
\hline \multirow[t]{2}{*}{ Parameters } & \multicolumn{4}{|c|}{ Cultivation method } \\
\hline & SRI & RMP & \% change in SRI & $\mathrm{LSD}_{.05}$ \\
\hline Root depth (cm) & 32.33 & 19.61 & +64.9 & 2.88 \\
\hline Root dry weight (g hill-1) & 11.10 & 5.33 & +108.3 & 1.47 \\
\hline Root dry weight $\left(\mathrm{g} \mathrm{m}^{-2}\right)$ & 277.42 & 266.33 & +4.2 & Ns \\
\hline Root volume (ml hill $\left.{ }^{-1}\right)$ & 47.93 & 21.47 & +123.2 & 4.77 \\
\hline Root volume $\left(\mathrm{ml} \mathrm{m}^{-2}\right)$ & 1198.33 & 1073.33 & +11.6 & Ns \\
\hline Root length (cm hill $\left.{ }^{-1}\right)$ & 7378.53 & 3560.53 & +107.2 & 566.81 \\
\hline Root density* $\left(\mathrm{cm}^{-2}\right)$ & 6.26 & 3.02 & +107.3 & 0.14 \\
\hline Amount of exudates $\left(\mathrm{g} \mathrm{hill}{ }^{-1}\right)$ & 6.43 & 2.33 & +176.0 & 0.66 \\
\hline Amount of exudates per $\mathrm{m}^{2}\left(\mathrm{~g} \mathrm{~m}^{-2}\right)$ & 160.70 & 116.50 & +37.9 & 19.61 \\
\hline Rate per hill (g hill ${ }^{-1} \mathrm{~h}^{-1}$ ) & 0.27 & 0.10 & +170.0 & 0.03 \\
\hline Rate per $\mathrm{m}^{2}\left(\mathrm{~g} \mathrm{~m}^{-2} \mathrm{~h}^{-1}\right)$ & 6.70 & 4.85 & +38.1 & 0.82 \\
\hline
\end{tabular}

*Volume of soil evaluated was $1,178 \mathrm{~cm}^{3}$

Source: Thakur et al. (2010) 
The rate at which these exudates are transported from the root toward the shoot, significantly higher in SRI plants, is an index of root physiological activity. It affects, i.e., potentially delays, the onset of leaf senescence, since these exudates contain plant hormones such as cytokinin (San-oh et al., 2004; 2006). Rice plants with a larger number of crown roots and root apices have been seen to synthesize larger amounts of cytokinins when each hill contains just one plant compared to each hill containing three plants (San-oh et al., 2006).

Planting of one seedling per hill with SRI methods is similar to the treatments in the experiments of San-oh and associates. SRI plants with better root growth and higher physiological activity may well be transporting larger amounts of cytokinins from roots to shoot. This would result in a lower rate of leaf senescence (San-oh et al., 2006; Soejima et al., 1992, 1995), something that is widely reported by farmers who use SRI methods.

In SRI plants, delayed senescence could derive from their having greater root growth, higher chlorophyll content, and perhaps more genetic expression of enzymes that contribute to photosynthesis during the latter part of the growth cycle (Ookawa et al., 2004; Suzuki et al., 2001). Unfortunately, relatively little research has been done on physiological factors associated with rice roots. This could reflect the extent of rice root degeneration under present continuous flooding (Kar et al., 1974), which would make studying their physiology difficult and evidently less interesting. The degradation of roots systems due to hypoxia makes rice plants into 'closed systems' before the end of the crop cycle. The translocation of $\mathrm{N}$ and other elements from leaves and stalks to grains becomes more important than when roots remain healthy and transport nutrients throughout the cycle, taking them up from the soil the whole time.

\section{CHLOROPHYLL CONTENT, PHOTOSYNTHESIS,} AND WATER USE EFFICIENCY (WUE)

Having intact and functioning root systems improves the rice plant canopy's ability to function, specifically, its ability to maintain more chlorophyll content for better light utilization and higher rates of photosynthesis, especially during the latter phases of growth. Research at the Water Technology Centre in Bhubaneswar found that SRI flag leaves at the middle ripening stage had significantly higher chlorophyll content (30.6\%) and also a higher photosynthesis rate, 89.3\% more than RMP leaves (Table 12). On the other hand, RMP plants had a higher transpiration rate due to their greater stomatal conductance, which meant that they emitted more water vapor than SRI plants. The calculated rate of water use efficiency (the ratio of photosynthesis to transpiration) was accordingly considerably higher in SRI compared to RMP plants, indeed more than twice as high. SRI plants fix ed $3.6 \mu \mathrm{mol}$ of $\mathrm{CO}_{2}$ for every one millimol of water lost, while RMP plants fixed $1.6 \mu \mathrm{mol}$ of $\mathrm{CO}_{2}$ per millimol of water transpired.

Associated with the greater root growth in SRI hills is the maintenance of greater chlorophyll content and higher rates of photosynthesis in the flag leaf and lower leaves $\left(4^{\text {th }}\right.$ leaf) during the later phase of grain ripening, according to earlier research (Thakur et al., 2010a). In SRI plants, it was seen that the chlorophyll content of leaves decreased considerably at the late-ripening (LR) stage, by $34 \%$ compared to earlier flowering (FL) stage. However, it was determined that the decrease in chlorophyll in the leaves of RMP plants was $48 \%$, half again as much (Table 13).

Table 12. Comparison of flag leaf chlorophyll content, transpiration rate, net photosynthetic rate, stomatal conductance, and instantaneous water use efficiency in SRI and RMP at middle-ripening stage

\begin{tabular}{|c|c|c|c|c|}
\hline \multirow{2}{*}{ Parameters } & \multicolumn{4}{|c|}{ Cultivation method } \\
\hline & SRI & RMP & \% change in SRI & $\mathrm{LSD}_{.05}$ \\
\hline Total chlorophyll (mg g $\left.{ }^{-1} \mathrm{FW}\right)$ & 3.37 & 2.58 & +30.6 & 0.11 \\
\hline Transpiration $\left(\mathrm{m} \mathrm{mol} \mathrm{m} \mathrm{m}^{-2}\right)$ & 6.41 & 7.59 & -15.6 & 0.27 \\
\hline Net photosynthetic rate $\left(\mu \mathrm{mol} \mathrm{m} \mathrm{s}^{-1}\right)$ & 23.15 & 12.23 & +89.3 & 1.64 \\
\hline Stomatal conductance $\left(\mathrm{m} \mathrm{mol} \mathrm{m} \mathrm{m}^{-2} \mathrm{~s}^{-1}\right.$ & 422.73 & 493.93 & -14.4 & 30.12 \\
\hline Instantaneous WUE $\left(\mu \mathrm{mol} \mathrm{CO}_{2} / \mathrm{m} \mathrm{mol} \mathrm{H}_{2} \mathrm{O}\right)$ & 3.61 & 1.61 & +124.1 & 0.42 \\
\hline Grain yield (ton ha-1) & 6.38 & 4.49 & +42.1 & 0.18 \\
\hline
\end{tabular}

RMP: Recommended management practices, from Central Rice Research Institute, Cuttack

WUE: Water use efficiency

Source: Thakur et al. (2010)

Table 13. Changes in leaf chlorophyll content and photosynthesis rate at different growth stages in SRI and RMP

\begin{tabular}{|c|c|c|c|c|c|}
\hline \multirow{2}{*}{ Parameters } & \multirow{2}{*}{ Cultivation method } & \multicolumn{3}{|c|}{ Growth stages } & \multirow[t]{2}{*}{ \% decrease from FL-LR } \\
\hline & & FL & MR & LR & \\
\hline \multirow{3}{*}{$\begin{array}{l}\text { Chlorophyll content } \\
\left(\mathrm{mg} \mathrm{g}^{-1} \mathrm{FW}\right)\end{array}$} & SRI & 3.09 & 2.93 & 2.04 & 33.98 \\
\hline & RMP & 2.96 & 2.35 & 1.53 & 48.31 \\
\hline & $\operatorname{LSD}_{0.05}$ & 0.03 & 0.13 & 0.08 & - \\
\hline \multirow{3}{*}{$\begin{array}{l}\text { Photosynthesis rate } \\
\left(\mu \mathrm{mol} \mathrm{m}^{-2} \mathrm{~s}^{-1}\right)\end{array}$} & SRI & 21.44 & 17.03 & 11.34 & 47.11 \\
\hline & RMP & 19.34 & 13.50 & 7.60 & 60.70 \\
\hline & $\operatorname{LSD}_{0.05}$ & 0.62 & 0.10 & 0.46 & - \\
\hline
\end{tabular}

RMP: Recommended management practices, from Central Rice Research Institute, Cuttack

FW: fresh weight; FL: Flowering stage; MR: Middle-ripening stage; LR: Late-ripening stage 
The rate of photosynthesis in leaves at the lateripening stage (LR), compared to the flowering stage (FL), was $60 \%$ lower in RMP plants, one-third more than the $47 \%$ decline in SRI plants. The photosynthates produced by this process are transported both to the roots, to support their metabolism, and to the tillers for grain filling. While this flow invariably attenuates toward the end of the crop cycle as plants mature and grain ripens, SRI plants have $28 \%$ more photosynthate to maintain greater root activity and for better grain filling than do RMP plants.

Depending upon the species and the developmental stage of a plant, on average between 25 and $50 \%$ of the photosynthates produced per day in the shoot are allocated to the plants' roots for growth, maintenance and other functions, like ion uptake. Beyond the seedling stage, there is a close relationship between root growth and photosynthesis in the canopy, so any limitations on photosynthesis inhibit root growth more than shoot growth. SRI management with its resulting greater promotion of photosynthesis can support the production of new roots and greater root biomass, such as seen in Figures 1 and 2. SRI performance can most simply be explained in terms of the positive feedback association between root and shoot growth; the more of either supports more of the other.

\section{DISCUSSION AND LOOKING AHEAD}

Experience with SRI is sounding an 'agronomic wake-up call' for the rice research and agricultural development communities at a time when long-standing assumptions about the best agronomic and water management practices for rice cultivation are due for review. Rice farmers in many parts of the world face growing limitations on freshwater for agricultural use, and they are confronted with rising economic and environmental costs of inorganic fertilization (Zhao et al., 2009). Current beliefs justify continuous flooding, despite root system asphyxiation and creation of a reduced soil chemical environment, and high plant density, despite constraints that this imposes on tillering and root growth and its high seed requirement, up to $100 \mathrm{~kg} \mathrm{ha}^{-1}$ or even more, as well as ever-increasing applications of inorganic fertilizers, despite their diminishing returns.

The originator of SRI, Fr. Henri Laulanié, showed that the contrary practices of maintaining aerobic soil conditions, such as through alternate wetting and drying (AWD), and optimizing plant sparsity rather than plant density, as well as organic fertilization, can be more productive, especially when starting with very young seedlings. This was true even on soils considered very 'poor' in terms of their chemical properties. The critical proviso, as we now understand better than he did, is that plant, soil, water and nutrient management practices need to mobilize the benefits and services of the soil biota interacting with and within larger root systems.

Laulanié's recommendations were empirically derived, based on observations and experimentation without benefit of formal agronomic research. Numerous studies in the peer-reviewed literature have now documented the merits of more aerobic soil management and reduced plant populations. These effects are heightened, often dramatically, when combined with the transplanting of very young seedlings and increased applications of organic matter for the soil (Chapagain and Yamaji, 2009; Mishra and Salokhe, 2008, 2010; Thakur et al., 2010a, 2010b, 2010; Zhao et al., 2009, 2010; Yang et al., 2004 ).

The insights and recommendations of this priestagronomiston have led farmers, researchers and policymakers to re-open whaton had been thought to be settled agronomic questions. Current understanding of how to produce rice crops with higher factor productivity, and in ways that are environmentally friendly and socially more beneficial, is undergoing revision. SRI methodology is assigning to plant roots and associated soil biota the justifiable and fundamental priority that they deserve.

The same kind of realization is gaining ground in agronomic theory and practice with regard to tillage. Several decades ago, it was a strongly-held conviction, among scientists as well as among farmers, that rainfed crop production requires thorough ploughing of the soil, a belief held as firmly as the assertion that rice is best grown in standing water. ${ }^{5}$ Minimum tillage, no-till and zero-till cultivation when first proposed and practiced were widely dismissed, and even deprecated as a primitive, atavistic kind of agriculture. This dismissal was uninformed by much if any knowledge of how roots and soil biota function. The steadfast defense of tillage was done with little appreciation of the complexity and dynamism of soil systems (Uphoff et al., 2006) or of the critical roles played by what can be summarized as 'the life in the soil' for achieving and maintaining soil system fertility and sustainability.

Iton has taken three decades to gain respectability and acceptance for what is now consolidated under the rubric of Conservation Agriculture (Friedrich et al., 2009). CA is defined by the simultaneous practical application of three principles: continuous minimum mechanical soil disturbance through no-till soil management and direct seeding of crops; permanent organic soil cover through cover crops and crop residue; and diversification of crop species grown in sequence or associations (www.fao.org/ag/ca).

Under CA, mechanical tillage is replaced by biological tillage -- by crop roots and through the activity of soil fauna and other organisms. There are now more than 110 million ha globally under CA across all continents, all agroecological zones, and all farm sizes. The three principles of CA promote the production of larger root systems for all participating crops and the proliferation of diverse soil organisms. With reduction or cessation of mechanical tillage, there is increased agrobiodiversity above and below ground surface, as the soil's biological, physical, chemical and hydrological environments are improved.

\footnotetext{
One of the leading reference books on rice production states: "Rice... thrives on land that is water saturated, or even submerged, during part or all of its growth cycle... Most rice varieties maintain better growth and produce higher yields when grown in a flooded soil" (De Datta, 1981: 41, 297-298, emphasis added)
} 
The full potential of both SRI and CA as innovative systems of agricultural production has yet to be realized because both are still 'works in progress.' The agronomic and water management practices of SRI are quite different from those applied in conventional wetland rice systems, where holding ponded water in rice paddies and puddling the soil during land preparation were unquestioned norms. Puddling was a holdover from past practice when it was done mainly for controlling weeds and to reduce the percolation of ponded water. Puddling, however, de-structures the soil, and together with flooding it demolishes the aerobic microorganism populations that live in the soil, contributing to declining productivity in continuous rice cropping systems (Reichardt et al., 2001).

Paddies, created over a long period of time, have a hard pan which holds water but also severely restricts the growth of root systems and the volume of soil that can be explored and utilized by root systems. We are now seeing that unpuddled direct-seeded rice can maintain the soil in a better condition and can offer improved crop performance (Hobbs and Gupta, 2004; Mohanty et al., 2004; Saharawat et al., 2010).

Appreciating these relationships and interactions suggests that the elements of CA and SRI can be adapted and combined for rainfed, i.e., non-irrigated, rice cultivation, with the aim of enhancing root growth and crop performance of rice grown according to SRI principles and practices, including no-till, direct-seeded SRI. This could save additional labor, energy and water because of no puddling and the maintenance of soil organic cover. Already farmers in Cambodia, China and India have started adapting SRI crop, water and nutrient management to zero-tillage on flat fields or permanent raised beds.

Systematic research is required to further evaluate and adapt SRI agronomic and water management practices to operate within a CA cropping system's framework so that soil puddling can be done away with, and directseeded rice or transplanting seedlings into undisturbed soil or into raised beds can be promoted. SRI has shown that rice and its root system can be more productive under mainly aerobic soil conditions. Work in North Korea and China on permanent beds and in India on double no-till wheat-rice cropping systems in the Indo-Gangetic Plains indicates that this is possible and can offer further cost reductions and environmental benefits and greater profit (Hobbs et al., 2008; Saharawat et al., 2010). Indeed, CAbased SRI cropping systems would offer robust sustainable production systems that would harness the combined advantages of both SRI and CA for enhanced root and soil interactions and productivity.

Most agricultural soils, including those used for irrigated wetland rice production, no longer provide a suitable living environment for the microorganisms that are so critical to their productive functioning. Microorganisms and even roots do not flourish in most farming systems, including rice-based systems that rely on mechanical tillage and puddling, which disrupts the soil and destabilizing soil habitats. In heavily puddles rice soils, the wrong kinds of organisms, including root-feeding nematodes, eventually take over. A CA-SRI system would allow for the creation of the best soil environment for expression of root growth for rice as well as for other crops in the cropping system, leading to a more complete harnessing of soil biological processes in time and space, which currently play a minor role in most crop production systems, even though the importance of biological nitrogen fixation, phosphorus-mobilizing mycorrhiza, and nutrient root pumps are well-known to agriculturalists.

A CA-SRI system would have a built-in system of biological tillage through enhanced root systems of rice (Figure 1 and 2; Tables 1 and 2) as well as of the other crops participating in the cropping system. Given the mostly soil aerobic soil conditions of the SRI component of such a cropping system, it should be possible to further enhance biological tillage by introducing non-traditional crops including trees and shrubs with deep-penetrating tap roots. Some of these so-called 'pioneer crops' such as lupine, finger millet, jackbeans or radish can break subsoil compactions such as hard pans in rice paddies, if planted in the crop rotation or in intercrop associations as green manures or cover crops (Bunch, 2006). Evidence shows that mineral fertilization requirements, particularly of $\mathrm{N}$ and $\mathrm{P}$, decrease in soils that on have been under CA practices for extended periods of time, and the problem of low availability or immobilized P in soil is ameliorated, even when soil analyses do not show high quantities of soluble P (FAO, 2009; Turner et al., 2006).

Much more remains to be known both scientifically and practically about how best to manage plants, soil, water and nutrients in combination, under a range of soil, climatic, topographic and other conditions, to achieve the most effective root development and functioning, in association with beneficial soil organisms. Strategies for 'rhizosphere management' (Liu et al., 2006) deserve much more investigation and investment. The System of Rice Intensification has already evolved and expanded a great deal over the last decade since it first began gaining acceptance outside of Madagascar. Especially given the drought and other effects of climate change, understanding how to give crops the most secure and supportive underground environment possible will become an ever-greater concern in the $21^{\text {st }}$ century.

\section{ACKNOWLEDGMENTS}

We wish to thank Dr. Youssef Yanni in the Department of Microbiology, Sakha Agricultural Research Station in Egypt for helpful comments and criticisms on a draft of the paper. Responsibility for any shortcomings in this paper of course remains with the authors.

\section{REFERENCES}

Andriankaja, A.H. 2001. Mise en evidence des opportunites de developpement de la riziculture par adoption du SRI et evaluation de la fixation biologique de l'azote: Cas des rizieres des hautes terres. Memoire de fin d'etudes. École Supérieure des Sciences Agronomiques, University of Antananarivo, Antananarivo.

Barison, J. 1998. Perspective de developpement de la region de Ranomafana: Les méchanismes physiologiques $d u$ riz sur de bas-fonds: Case $d u$ $S R I$. Mémoire de fin d'etudes. École Supérieure 
des Sciences Agronomiques, University of Antananarivo, Antananarivo.

Barison, J. 2003. Nutrient-use efficiency and nutrient uptake in conventional and intensive (SRI) cultivation systems in Madagascar. M.Sc. thesis for Department of Crop and Soil Sciences, Cornell University, Ithaca, NY.

Bottini, R., M. Fulchieri, D. Pearce and R.P. Pharis. 1989. Identification of gibberellins A1, A3 and iso-A3 in cultures of Azospirillum lipoferum. Plant Pathology, 90:45-47.

Bunch, R. 2006. Green manures/cover crops for recuperating soils and maintaining soil fertility in the tropics. In: Biological Approaches to Sustainable Soil Systems, eds. N. Uphoff et al., 439-452. CRC Press, Boca Raton, FL.

Ceesay, M., W.S. Reid, E.C.M. Fernandes and N. Uphoff. 2006. Effects of repeated soil wetting and drying on lowland rice yield with System of Rice Intensification (SRI) methods. International Journal of Agricultural Sustainability, 4:5-14.

Chapagain, Tejendra and E. Yamaji. 2009. The effects of irrigation method, age of seedling and spacing on crop performance productivity and water-wise rice production in Japan. Paddy and Water Environment, DOI 10.1007/s10333-009-0187-5.

Coleman, D.C., D.A. Crossley and P.F. Hendrix. 2004. Fundamentals of Soil Ecology. Elsevier, Amsterdam.

Cook, G. 2009. Aceh Update: Rice aplenty in Aceh. Caritas News, Spring, 10-11.

DeDatta, S.K. 1981. Principles and Practices of Rice Production. John Wiley, New York.

FAO. 2009. Increasing Crop Production Sustainabliy: The Perspective of Biological Processes. Food and Agriculture Organization, Rome.

Friedrich, T., A.H. Kassam and F. Shaxson. 2009. Conservation Agriculture. In: R. Meyer (Eds.). Agriculture Technologies for Developing Countries: Final Report of Science and Technology Options Assessment Project. Annex 1. European Technology Assessment Group, Karlsruhe.

Gayathry, G. 2002. Studies on dynamics of soil microbes in rice rhizosphere with water saving irrigation and in-situ weed incorporation. Thesis submitted to Tamil Nadu Agricultural University, Coimbatore, Tamil Nadu, India.

Hobbs, P.R. and R.K. Gupta. 2004. Problems and challenges of no-till farming for the rice-wheat systems of the Indo-Gangetic Plains in South
Asia. In: R. Lal, P. Hobbs, N. Uphoff and D.O. Hansen (Eds.). Sustainable Agriculture and the Rice-Wheat System. Marcel Dekker, New York. p. 101-121.

Hobbs, P., K. Sayer and R. Gupta. 2008. The role of conservation agriculture in sustainable agriculture. Philosophical Transactions of the Royal Society, 363:543-555.

Anas, I., R. Widyastuti, T.R. Hutabarat, D. Nareswari, I.A. Hakim, A. Ningtyas, S.K. Santoso, W. Agusmiati, M. Ulfah and E.N. Sari. 2009. Greenhouse Gases Emission and Biodiversity under the System of Rice Intensification (SRI). International Conference on Promising Practices for the Development of Sustainable Paddy Fields, PAWEES 2009. Bogor, Indonesia 7-9 October 2009.

Kar, S., S.B. Varade, T.K. Subramanyam and B.P. Ghildyal. 1974. Nature and growth pattern of rice root system under submerged and unsaturated conditions. Il Riso, 23:173-179.

Kassam, A.H., T. Friedrich, F. Shaxson and J. Pretty. 2009. The spread of Conservation Agriculture: Justification, sustainability and uptake. International Journal of Agricultural Sustainability, 7:292-320.

Laulanié, H. 1993. Le système de riziculture intensive malgache. Tropicultura, 11:110-114.

Leesawatwong, M., S. Jamjod, J. Kuo, B. Dell and B. Rerkasem. 2005. Nitrogen fertilizer increases seed protein and milling quality of rice. Cereal Chemistry, 82:588-593.

Liu, X.J., L. Li and F.S. Zhang. 2006. Rhizosphere management as part of intercropping and ricewheat rotational systems. In: Biological Approaches to Sustainable Soil Systems (Eds.) N. Uphoff et al., CRC Press, Boca Raton, FL. p. 559-574.

Mishra, A. and V.M. Salokhe. 2008. Seedling characteristics and early growth of transplanted rice under different water regimes. Experimental Agriculture, 44:1-19.

Mishra, A. and V.M. Salokhe. 2010. The effects of planting pattern and water regime on root morphology, physiology and grain yield of rice. Journal of Agronomy and Soil Sciences, on-line.

Mohanty, M., D.K. Painuli, and K.G. Mandal. 2004. Effect of puddling intensity on temporal variation in soil physical conditions and yield of rice (Oryza sativa) in a vertisol of central India. Soil and Tillage Res., 76:83-94. 
Moser, C.M. and C.B. Barrett. 2003. The disappointing adoption dynamics of a yield-increasing, low external-input technology: The case of SRI in Madagascar. Agricultural Systems, 76:1085-1100.

Namara, R., D. Bossio, P. Weligamage and I. Herath. 2008. The practice and effects of the System of Rice Intensification (SRI) in Sri Lanka. Quarterly Journal of International Agriculture, 47:5-23.

Nemoto, K., S. Morita and T. Baba. 1995. Shoot and root development in rice related to the phyllochron. Crop Science, 35:24-29.

Nisha, P.T. 2002. Physiological responses of rice hybrids CORH2 and ADTRH1 to integrated crop management techniques. Thesis submitted to Tamil Nadu Agricultural University, Coimbatore.

Ookawa, T., Y. Naruoka, A. Sayama and T. Hirasawa. 2004. Cytokinin effects on ribulose-1,5bisphosphate carboxylase/oxygenase and nitrogen partitioning in rice during ripening. Crop Science, 44:2107-2115

Puard, M., P. Couchat, and G. Lasceve. 1989. Etude des mecanismes d'adaptation du riz aux contraintes du milieu. I: Modification de l'anatomie cellulaire. L'Agronomie Tropicale, 44:156-173.

Randriamiharisoa, R. 2002. Research results for biological nitrogen fixation with the System of Rice Intensification. In N. Uphoff et al., (Eds.). Assessments of the System of Rice Intensification: Proceedings of an International Conference, Sanya, China, April 1-4, 2002. CIIFAD, Ithaca, NY. p. 148-157.

Randriamiharisoa, R. and N. Uphoff. 2002. Factorial trials evaluation of the separate and combined effects of SRI practices. In N. Uphoff et al., (Eds.). Assessments of the System of Rice Intensification: Proceedings of an International Conference, Sanya, China, April 1-4, 2002. CIIFAD, Ithaca, NY. p. 148-157.

Randriamiharisoa, R., J. Barison and N. Uphoff. 2006. Soil biological contributions to the System of Rice Intensification. In: Biological Approaches to Sustainable Soil Systems, eds. N. Uphoff et al., 409-424. CRC Press, Boca Raton, FL.

Reichardt, W., A. Brioes, R.D. Jesus and B. Padre. 2001. Microbial population shifts in experimental rice systems. Applied Soil Ecology, 17:151-163.

Rupela, O.P., S.P. Wani, M. Kranthi, P. Humayun, A. Satyanarayana, V. Goud, B. Gujja, P. Punnarao, V. Shashibhushan, D.J. Raju, and P.L Reddy. 2006. Comparing soil properties of farmers' fields growing rice by SRI and conventional methods. In: Proceedings of 1st National SRI Symposium, 17-18 November. World Wide Fund for Nature-
ICRISAT Dialogue Project, Patancheru, Hyderabad.

Sah, R.N. and D.S. Mikkelsen. 1983. Availability and utilization of fertilizer nitrogen by rice under alternate flooding. II: Effects on growth and nitrogen use efficiency. Plant and Soil, 75:227234.

Saharawat, Y.S., B. Singh, R.K. Malik, J.K. Ladha, M. Gathala, M.L. Jat and V. Kumar. 2010. Evaluation of alternative tillage and crop establishment methods in a rice-wheat rotation in North Western IGP. Field Crops Res., 116:260267.

San-oh, Y., Y. Mano, T. Ookawa and T. Hirasawa. 2004. Comparison of dry matter production and associated characteristics between direct-sown and transplanted rice plants in a submerged paddy field and relationships to planting patterns. Field Crops Res., 87:43-58.

San-oh, Y., T. Sugiyama, D. Yoshita, T. Ookawa and T. Hirasawa. 2006. The effect of planting pattern on the rate of photosynthesis and related processes during ripening in rice plants. Field Crops Res., 96:113-124.

Sato, S. and N. Uphoff. 2007. A review of on-farm evaluation of system of rice intensification (SRI) methods in eastern Indonesia. $C A B$ Review: Perspectives in Agriculture, Veterinary Science, Nutrition and Natural Resources, 2:1-12.

Sinha, S. K. and J. Talati. 2007. Productivity impacts of the System of Rice Intensification (SRI): A case study in West Bengal, India. Agricultural Water Management, 87:55-60.

Soejima, H., T. Sugiyama and K. Ishihara. 1992. Changes in cytokinin activities and mass spectrometric analysis of cytokinins in root exudates of rice plant (Oryza sativa L.). Plant Physiology, 100:1724-1729.

Soejima, H., T. Sugiyama and K. Ishihara. 1995. Changes in the chlorophyll contents of leaves and in levels of cytokinins in root exudates during ripening of rice cultivars Nipponbare and Akenohoshi. Plant and Cell Physiology, 36:1105-1114.

Sommers, E., D. Ptacek, P. Gysegom, M. Srinivasan and J. Vanderleyden. 2005. Azospirillum brasiliense produces the auxin-like phenylacetic acid by using the key enzyme of indole-3-acetic acid biosynthesis. Applied and Environmental Microbiology, 71:1803-1810.

Suzuki, Y., A. Makino and T. Mae. 2001. Changing in the turnover of Rubisco and levels of mRNAs of rbcL and rbcS in rice leaves from emergence to 
senescence. Plant Cell and Environment, 24:1353-1360.

Thakur, A.K., N. Uphoff and E. Antony. 2010a. An assessment of physiological effects of system of rice intensification (SRI) practices compared to recommended rice cultivated practices in India. Experimental Agriculture, 46:77-98.

Thakur, A.K., S. Rath, S. Roychowdhury and N. Uphoff. 2010b. Comparative performance of rice with system of rice intensification (SRI) and conventional management using different plant spacings. Journal of Agronomy and Crop Science, 196:146-159.

Todorov, M.T. 1995. Rice yield and its biological value of protein fertilized with an increased rate of mineral fertilizers. Cahiers Options Méditerranéennes, 15:65-70.

Turner, B., E. Frossard and A. Oberson. 2006. Enhancing phosphorus availability in low-fertility soils. In N. Uphoff et al., (Eds.). Biological Approaches to Sustainable Soil Systems. CRC Press, Boca Raton, FL. p. 191-206.

Uphoff, N. 2005. The development of the System of Rice Intensification. In J. Gonsalves et al., (Eds.). Participatory Research and Development for Sustainable Agriculture and Rural Development. International Development Research Centre, Ottawa. p. 119-125.

Uphoff, N., A. Ball, E.C.M. Fernandes, H. Herren, O. Husson, M. Laing, C.A. Palm, J. Pretty, P. Sanchez, N. Sanginga, and J. Thies, eds. 2006. Biological Approaches to Sustainable Soil Systems, Boca Raton, FL.

Uphoff, N. 2010. Agroecological approaches to 'climateproofing' the agricultural sector while also raising its productivity in the 21st century.
Chapter to be published in proceedings from OECD conference on soil systems and climate change, Madison, WI, June 2009.

Uphoff, N., I. Anas, O.P. Rupela, A.K. Thakur and T.M. Thiyagarajan. 2009. Learning about positive plant-microbial interactions from the System of Rice Intensification. Aspects of Applied Biology, 98:29-54.

Uphoff, N. and A. Kassam. 2009. Case Study: System of Rice Intensification. In: R. Meyer (Eds.). Agricultural Technologies for Developing Countries: Final Report of Science and Technology Options Assessment Project, Annex 3. European Technology Assessment Group, Karlsruhe.

Whalen, J.K. and L. Sampedro. 2010. Soil Ecology and Management. CABI, Wallingford.

Yang, C.M., L.H. Yang, Y.X. Yang and O.Y. Zhu. 2004. Rice root growth and nutrient uptake as influenced by organic matter and alternately flooded paddy soils. Agricultural Water Management, 70:67-81.

Yoshida, S. 1981. Fundamentals of Rice Crop Science. International Rice Research Institute, Manila.

Zhao, L.M., L.H. Wu, Y.S. Li, X.H. Lu, D.F. Zhu and N. Uphoff. 2009. Influence of the System of Rice Intensification on rice yield and nitrogen and water use efficiency with different $\mathrm{N}$ application rates. Experimental Agriculture, 45:275-286.

Zhao, L.M., L.H. Wu, Y.S. Li, S. Animesh, D.F. Zhu and N. Uphoff. 2010. Comparisons of yield, water use efficiency, and soil microbial biomass as affected by the System of Rice Intensification. Communications in Soil Science and Plant Analysis, 41:1-12. 